\title{
The power \\ of language: moving \\ beyond past harms and present
hurts
}

\section{Alison Williams}

Language matters [because] it contains and conveys the categories through which we understand ourselves and others, and through which we become who and what we are.

Lynne Tirrell (2000, p. 139)

Much of this book concerns language: what is said, who says it, how it is said and in what context, what meaning we attach to it, and how we react to it. Fifty-seven of the recipes and papers refer directly or indirectly to language: its use, its misuse, and its power. Authors describe times when language has been alien or absent, when they have - or have not been able to access the words they needed in the moment, and they talk about the impact - positive and negative that language (their own and others') has on their ability to work well, collaboratively, creatively and productively.

Language conveys layers of meaning. The structure of linguistic categories reinforces social categories, which in turn reinforce (and can create) patterns of behaviour, which are then reflected in the original linguistic categories (Tirrell, 2000). As Braidotti observes of how androcentric concepts 
are embedded historically, "the thinker needs some humility before the multilayered and complex structure of language" (Braidotti, 2000, p. 300). An in-depth analysis of feminist philosophical approaches to language is beyond the scope of this book. We point the interested reader to The Companion to Feminist Philosophy, and in particular to the essays by Tirrell and Braidotti.

The dictionary records cultural meanings, which we take to be descriptive, no matter who is speaking. It is, for example, only in the present century that it has been fully accepted that the title of Chairman is not (only) a description of a role, but a reinforcement of social norms and stereotypes. The change to the title of Chair was initially strongly opposed; on taking over the role, one academic colleague found herself having to protest that while she did not object to being called a chair, she did object to being called a man.

\section{Exorcising the ghosts of past harms}

Like the Chair/Chairman shift, many of the ways in which language has harmed women by erasing them from the discourse - past harms - have been challenged, and are now officially gone. However, as recipes such as Damning with faint praise and Unravelling rhetoric attest, some still arise and continue to have to be challenged. Recipes Challenging bias and Allies in the classroom point up the need to cultivate personal awareness to notice these harms in the first place, so normalised as they are, as well as the vocabulary to challenge them.

One of the most pervasive is the false generic. We all have pet hates: mine is guys - it is not inclusive, and at a recent undergraduate seminar the raising of this sparked a very difficult debate. (For suggestions about managing these kinds of discussions see Creating a safe space for classroom discussions.) Although 'mankind' is rarely used now in academic work, androcentric language and its consequent thinking are still present in different guises. An editorial headline in The Lancet (2016) described a clinical trial as "First-in-man", as did the research paper itself (Kalladka et al., 2016). A leading piece in The Economist on climate change (2017) started: "For millennia mankind has moaned about the weather" and ends: "One thing is certain, mankind is forever cursed to moan about the weather" (http://worldif.economist.com/ article/13542/changing-climate-opinion). It is tempting to ask if human beings are forever cursed to use the false generic?

Tirrell's (2000) call "Stop it, now!" and Gay's exhortation to men to:

$$
\begin{aligned}
& \text { Make the effort and make the effort } \\
& \text { and make the effort until you no } \\
& \text { longer need to, until we don't need } \\
& \text { to keep having this conversation. } \\
& \text { Change requires intent and effort. It } \\
& \text { really is that simple. (Gay, 2014, p. 173) }
\end{aligned}
$$

are echoed, and practical ideas put forward in response, in Be vigilant with your vocabulary; say something; and Gender balancing your seminar speakers (among many others).
Address the issue: Make a decision to draw your colleague's attention to it immediately or wait until later when you can have a proper discussion. Humour is often useful in navigating potentially difficult situations as it de-escalates the threat of any confrontation while at the same time allowing you to navigate a potentially difficult situation with more ease. (From Be vigilant with your vocabulary).

\section{Present hurts}

Thirty-two of the recipes and papers explore how people in the University deal with language which contributes directly to gender inequalities, and 25 more contributions look at language's indirect impact. With raised awareness diminishing the more obvious harms, more subtle hurts come to the fore, many based on how language reinforces stereotype norms without our being aware of it, immersed as we are in the culture (see Recognise your privilege). For example, in his 2007 book The 
Stuff of Thought, Steven Pinker notes in parentheses, and apparently without irony,

(By the way, in this chapter I will refer to the generic speaker as a "he" and the generic hearer as a "she", just to help you keep track of who's who; this is a common convention in the linguistics literature). (Pinker, 2007, pp. 376-377)

Every time it is used, this 'common convention' reinforces the normalisation of men as worth listening to, and women as the receivers of their wisdom. Rebecca Solnit, in her essay Men explain things to me, describes the phenomenon of 'mansplaining' (although she does not use this term) when a man has explained to a woman, most often wrongly, things that they know little or nothing about, and in which the woman is an expert. Solnit is, however, clear that although this is in her experience usually a gendered activity it is not exclusively so; just "the intersection between overconfidence and cluelessness where some portion of [the male] gender gets stuck" (Solnit, 2012).

Tirrell points out that by producing and reproducing social and cultural norms in content, form and usage, language is normative. Much of what we think of as descriptive is in fact normative; it only appears descriptive if one has already accepted a rather large set of norms (Butler, 1993). For example, research into effective leadership qualities in research environments has identified the desirability of positive attitude, empathy, generosity, humour, open-mindedness and reliability (Robertson, 2014; Glaser \& Smalley, 1995). These leadership traits are often stereotyped as feminine and contrasted with leadership traits such as assertiveness, dominance, and competitive agentic behaviour that are stereotypically described as masculine (as in Schein's 1993 think manager - think male paradigm). Koenig et al. point out:

Even women who possess outstanding qualifications for leadership may have the burden of overcoming preconceptions that they are not well equipped to lead. Not only do the descriptive aspects of stereotyping make it difficult for women to gain access to leader roles, but the prescriptive aspects of stereotyping could produce conflicting expectations concerning how female leaders should behave. (Koenig et al., 2011, p. 637)

As well as creating barriers for women, this also makes it difficult for men to exhibit leadership qualities that are 'described' as feminine, without being thought of as soft or a pushover: "Gender norms are reinforced by everyone in the community" (Greene \& Levack, 2010). This is explored with honesty and clarity by senior University leaders in Leadership perspectives on gender equality and in Leadership styles and approaches in Geosciences.

\section{Other present hurts include:}

- $\quad$ The words we use in praising women differ from those used in praising men. Damning with faint praise and Raising your profile on a grant application look at the use of adjectives: 'grind' for women, 'stand-out' for men.

- Paper-cut comments (those little remarks that sting) and subtly sexist jokes contribute to the "drip, drip" effect (see Reflections on exercise and sport and Leadership perspectives on gender equality) that goes to create a "chilly climate" (see the illustration Microagressions).

- Language that trivialises: for example calling an underpaid employee a girl implies that she does not have real financial responsibilities, and so justifies the below-minimum pay level (Merriam, 1974). More than one female professor has been called "love" and one of the editors of this book and a fellow-professor have been addressed as "girls" by the servitor.

- Girl is a term of abuse when used by boys to other boys, as is sissy (Van der Gaag, 2014). 
How language is used in a wider societal context impacts everyone who works and studies in higher education. For example, Chimamanda Ngozi Adichie points out that "when we say fathers are 'helping', we are suggesting that child care is a mother's territory, into which fathers valiantly venture. It is not" (Adichie, 2017, pp. 13-14). Recipes The kids are alright and Deadlines and diapers: being an academic dad demonstrate how far beyond this position many people have moved; while How to convince your family to let you study suggests strategies to try with people who are still limited by social and cultural stereotypes.

The use of gendered pronouns (she, he) to maintain stereotypes and cultural norms is an area of growing importance as the trans and non-binary LGBTO+ community is more widely recognised and their status beyond a simple binary gender framework is appreciated. In a 2017 talk at the University of Edinburgh, Chad Gowler made an impassioned plea to be referred to as 'they' and 'them'. Although some may assume that, because of physical characteristics, Chad is female, Chad describes themself as non-binary, and without a definitive gender, so to be referred to as 'she' is both inaccurate and offensive.

It is interesting that my spell check underlines 'themself' in red, and autocorrects it to 'themselves'; the algorithmic reinforcement of gender norms is an area for future research. There is an entry in the Glossary about alternative gendered pronouns and their use, such as 'ze' or 'hir' (pronounced here) and where to access more detailed information. You may also find https://minus18. org.au/pronouns-app/interesting.

\section{Healing: moving beyond}

By understanding how language really works, we might just understand how the rabbit of normativity gets pulled from the hat of articulation. (Tirrell, 2000, pp. 139-140)
Tirrell asserts that: "Those who seek to change the social order must not ignore the language that embodies it" (2000, p. 141). Language, we suggest, is a powerful tool to use when change in institutions is, as Mackay says, "actively resisted or passively neglected" going on to argue that old rules and mores around gender are 'sticky' (Mackay, 2014, p. 551).

Many of the recipes tell the story of how their writers have become aware of the power of language to shape their own and others' perceptions and behaviours (see Raising your profile within your organisation and Talking about your achievements). The recipes share how individuals have found their voice, the words and phrases needed to express themselves and their ideas and feelings, the power to respond calmly and with authority rather than to react without thinking (see Finding my voice and Being visible in meetings).

A recurring theme is the authors' conscious awareness in the moment of language used, and their developing practice in both attention and response (see Pause). The recipes also chart how the ground has shifted over the past two years of the project, and how previously unconsciously biased colleagues (of both genders) are now using the language of equality (see Damning with faint praise and Leadership perspectives on gender equality). Over the course of this project we have developed, like Tirrell, "a dual consciousness which is aware of injustices in past and present social practices, and yet is marked by an apprehension of possible futures in which women can flourish" (Tirrell, 2000, p. 140).

Most women fight wars on two fronts, one for whatever the putative topic is and one simply for the right to speak, to have ideas, to be acknowledged to be in possession of facts and truths, to have value, to be a human being. (Solnit 2012). 